\title{
A study on information credibility in the social media marketing adoption: Evidence from Indonesia
}

Winarko, Hilarius Bambang $\measuredangle$

Sampoerna University, Indonesia (bambang.winarko@sampoernauniversity.ac.id)

Sihabudin, Ahmad

Universitas Sultan Ageng Tirtayasa, Indonesia (sihab@untirta.ac.id)

Dua, Mikhael

Atma Jaya Catholic University Jakarta, Indonesia (mikhael.dua@atmajaya.ac.id)

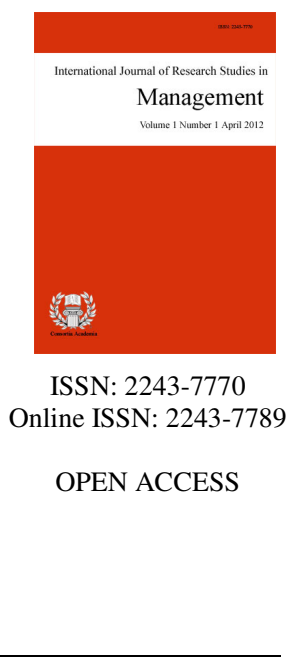

\section{Abstract}

This research is aimed to explore how the credibility factors such as medium and message credibility influence the information credibility in the context of adoption behavior, especially when young consumers are searching information for any promoted SME products or services offered through the social media networks. The quantitative methodology used by developing new research model based-on marketing communication theories to examine factors that significantly influence in the adoption process of digital marketing technique for SME markets. The results indicate that information credibility is significantly affected by the medium credibility and message credibility. Additionally the research found surprisingly that information credibility was not giving a strong affect directly toward millennial adoption on social media marketing platform. However the study found that the usage of social media marketing strategy to promote SME products and services was recommended effectively, especially targeting for the millennial consumer segments since they are considered as the important digital native generational consumers in Indonesia market.

Keywords: information credibility; social media marketing; digital marketing; millennial; SME; adoption 


\section{A study on information credibility in the social media marketing adoption: Evidence from Indonesia}

\section{Introduction}

According to Straubhaar, LaRose, and Davenport (2012), social media network, such as: Facebook, Twitter and YouTube now are becoming one of the main tools to gather public relations data and function as the vehicle to spread promotional message for corporations. These social media networks has expanded its role as their original function, evolving to be one of news information search, including entertainment and mixed communication medium among the communities used to be conducted through chat room, listserv, instant messenger and newsgroup. In-line with McLuhan's Laws of Media, social media network might create four phenomenon which are enabling to improve the society (enhancement), makes the information becomes obsolete faster (obsolescence), improve what was missing (retrieval), and able to change something from effective to be ineffective (reversal).

With the increasing use of digital information nowadays, social media network's role is becoming more important, especially in the changing of public relations within the marketing mix concepts. Public relations has been implementing by most of organizations, either by corporations, government institutions, non-profit organizations, as well as to promote the products and services offered by SMEs (Small and Medium Enterprises). Further research done by Li and Suh (2015) found that the information credibility of social media was affected significantly by two factors; they are: medium credibility and message credibility. Another research study by Hajli (2018) reported that in the online platform of social media networks, the information credibility can affect the consumer's social word-of-mouth adoption, whereby the social word-of-mouth is seen as the new form of electronic word-of-mouth (eWOM) detailing evaluation by consumers about a product using social media.

However, Word-of-Mouth strategy is having two sides like a knife that cut both ways for marketers. The informal discussions about any products among the consumers can boost or even drop the sales in the marketplace. Consumers may weigh negative word of mouth heavily rather than the positive one. When consumers consider a new product or service, they are likely to pay more attention firstly to negative information rather than positive information and to tell others about their unpleasant experiences. However, the WOM strategy might be effective when it is controlled by online communities who are discussed in a more closed group, because the negative information can be filtered, clarified, or even be corrected. Although initially driven by having fun motives, the social media subscribers are enjoying the commercial benefits to find alternative information to satisfy their consumption needs. This technology revolution apparently change the business models in many industries, especially because they empower end consumers to literally become partners and shape the markets, including SME products and services.

Because of its characteristics, the consumption of any offered products and services were driven by the perception of a society or consumers. According to some researches (Tambunan, 2009; IFC \& USAID, 2016), it reports that there are two main constraint factors commonly faced by SMEs in ASEAN, especially Indonesia, they are: financial access and marketing communication problems. The marketing communication constrain factor might affect directly to the growth and sustainability of SMEs, because its products as well as brands are not widely known by consumers compared to major big corporations. The innovation development of digital marketing communication technology by using social media platform might be used as an alternative way to overcome this constraint factor, although there are limitations on its features.

The widely use of social media networks for commercial aims, especially for promotional tools has been growing more popular than ever. However the information credibility issue may occur since social media platform also been used by political campaign to disseminate incredible or exaggerated news information. The 
A study on information credibility in the social media marketing adoption: Evidence from Indonesia

study conducted by Priambodo (2016) reports the Indonesian public perceptions towards the online news, where more than $58 \%$ of the respondents don't trust the content of the news broadcasted through social medias, where most of them read the news through Facebook, Twitter, and Line. To address this problem, this study aimed to see further objectively the consistent effect of information credibility towards the adoption of social media platform as marketing communication tool used by SMEs, especially for the millennial typical consumer group in different social and political of Indonesia context.

Why the millennial are becoming an important target consumer? According to Indonesia population pyramid projection in 2020 by Indonesia National Statistic Body, it is predicted that the Indonesian millennial fall into productive age category of 20 to 40 years of age, which may become the Indonesian economy strength foundation with estimated 83 millions of population or about $34 \%$ from Indonesian total population which is predicted to reach 271 millions. Therefore the millennial who are living today, within the net two years are predicted to become the important targeted consumer who have sufficient buying power to consumer SMEs products and services because they are actively seeking the buying information from social media networks (Ali \& Purwandi, 2016).

These millennial consumer market segment is believed to be the first generational segmentation who adopts digital communication technologies via social media networks due-to its ubiquitous characteristics as alternative medium to communicate or interact, gather and share the information among of them relatively at the same time in various or different locations. Therefore the role of this "digital native" (Tuten \& Solomon, 2018) generational consumer is becoming more important than before for marketers, while various social media platforms also have been increasingly used by large corporations to market their products and services as well. This paper contributes significant research in the field of digital marketing technique, especially by using the social media platform to market SME products and services, which shows the most important predictor to measure its credibility of information.

\section{Literature Review}

As the Internet penetration has been growing from time to time, the Internet has been successfully used by consumers who seek for information online. Initially the commercial side of the Internet, especially the advertisement or promotion side, has met with consumer opposition, because advertisement is perceived by many to be an intrusion of consumers' activity over the Internet or it is something that is there to stall them from doing what they want to do online. However as time goes by, consumers are starting to realize that what they enjoy over the Internet is actually comes at a cost from advertisement placement and acceptance (Tuckwell, 2008). Social Media Marketing is one of the alternative solutions which might be of cost-effective compared to the traditional promotional ways of marketing SME products and services, especially for young consumer's market segment.

The existence of social media network can be seen as the behavior of people who use technology, more than the technology itself, not only merely to receive information, but the users are active users and consume I, even add the values of the websites (Campbell, Pitt, Parent, \& Berthon, 2011). The usage of Social Media Marketing creates a paradigm shift because the role of the consumer is changing due-to their involvement as part of the production of the value. This phenomenon is called as Co-Creation. The corporation and consumers have been traditionally seen as having different roles. The role of the corporation is to create brand awareness which offer benefits to consumers. Meanwhile the role of the consumer or the target market is being to passively consume the offered products. However in the postmodernism world, this traditional boundary has been blurred, because the clear division of production and consumption has been closer than ever (Parsons \& Maclaran, 2009). Therefore SME marketers need to spend more effort to co-create brand experiences with consumers that form an important part of building and maintaining brand culture. And this co-creation strategy has been enabled through the Social Media Marketing. 
Many definitions are proposed by the experts about social media. One of them as proposed by Charlesworth, (2009) defines that social media is a collective term from several kinds of social networks and community sites, including online applications, such as: blogs, podcasts, reviews and wikis. This definition is supported by a study done at 94 sociological definitions from community, which found four common elements. Those elements form the social media definition that involves: a group of people, who are interacted socially, its members have similar relations, and share something within a certain period (Hillery, 1955).

Further, a search engine optimation expert, Danny Sullivan reports that there are some variants of social media; they are: (1). Social News Sites (such as: Digg and Reddit); (2). Social Bookmarking Sites (such as: Delicious and StumbleUpon); (3). Social Networking (such as: Facebook, Myspace, and LinkedIn); (4). Social Knowledge (such as: Wikipedia and Yahoo Answers); and (5). Social Sharing (such as: YouTube, Flickr, Twitter, Instagram, Pinterest, and Tumblr). According to Cort (2014) online marketing communication through social media platform is the most popular tool used by SMEs in UK. Meanwhile, according to the research conducted by MarkPlus (2015) towards millennial-type respondent in 18 big cities in Indonesia, it found that there are three social media that are most popular used in Indonesia; they are: Facebook, Twitter, and Instagram.

The word-of-mouth (WOM) technique has been used widely as marketing promotion tool in social media marketing. Solomon, 2010, defines this marketing strategy as product information sent by one consumer to another. This technique is perceived as more reliable and trustable compared to the conventional marketing promotional message delivery by more formal traditional marketing channels. This advantage is supported by previous research that two third of consumer goods were sold effectively by applying this WOM technique. Different from conventional advertising, this new type of communication channel is categorized as personal communication through social media (Belch \& Belch, 2015) which enable to produce social pressures, so the purchase recommendation of the products and services can be done more effectively by marketers. The more positive the recommendation is given, the bigger the consumer intention to use the products. Nowadays there are more reputable companies which market their products and increase their brand awareness through WOM communication channel. This marketing communication technique is also called as marketing communication that is driven by consumer (consumer-generated marketing), buzz marketing, or viral marketing.

Hajli (2018), in his research found the idea on how a corporation can introduce their new products or services to the market by using more effective way through social media marketing. This phenomenon is driven by the potential problems currently faced by the communities or consumers who are intensively connected through the Internet, but have limitations on the information access of new products availability, which might probably fit to satisfy their needs, but only available in the conventional commercial transactions mode (offline). There are four factors that influence individuals or online communities in adopting the social media to seek trustable reference to find the products and services they need. They are: social WOM credibility, information usefulness, social support, and social media interactivity.

Prior study by Johnson and Kaye (2004) that measured the information credibility based-on ASNE (American Society of Newspaper Editors) and MORI Research, found that the reader's perception towards the modern Internet-based media in the form of Weblog showed more positively, although it was tend to be more bias compared to the traditional media. This finding can explain why people were eventually accepting the digital media even though there was still problem with the content of the message. From time to time the adoption of the new digital media has been implemented globally not limited in the advanced economic countries, but also in the developing country like Indonesia.

The research study about the factors that affects the information credibility of social media like Facebook was done by Rouhan Li and Ayoung Suh in 2015. This study was developed by using the theory of Elaboration Likelihood Model (ELM) as proposed by Richard E. Petty and John T. Cacioppo in 1986, to explain there are two important dimensions: medium credibility and message credibility that influence the information credibility of social media. According to Li and Suh (2015) information credibility is defined as the extent to which one 
A study on information credibility in the social media marketing adoption: Evidence from Indonesia

perceives information to be believable as well as is a strong predictor of an information consumer's further action, in this study context whether they want to adopt social media marketing technique to receive promotional messages or not.

Miller (2005) categorizes the ELM theory in the message processing theory which is later used in this study to examine the information credibility of social media marketing as a one of the proposed marketing communication channel to promote SMEs' products and services in Indonesia. This persuasive communication theory tried to predict when and how an individual might and might not be influenced by any promotional message. In this case a consumer can evaluate any promotional message either by elaborating his/her thinking process critically (called as "central route"), or through more simple way (called as "peripheral route"). The model used in this ELM theory has important implication for marketing communication, especially in the context of consumer involvement towards any promotional message. When the degree of involvement is high, the promotional message has strong argument so there is no other reason for consumer to accept it. But when the degree of involvement is low, the consumer will take an alternative communication way before he/she can accept it, which becomes a more important aspect compared to the strength of its message details.

Further in their development of information credibility construct model, Li and Suh (2015) uses the assumption that persuasive communication in the ELM theory was able to explain the roles of medium credibility and message credibility. If a consumer has ability to process or evaluate information credibility, he/she will take central route by considering the message content carefully. But if the consumer has minor ability to evaluate information credibility, then he/she may take peripheral route which spend more efforts to evaluate the medium that provide that information. Before the consumer takes the central route, he/she might need more considerations, such as the message content and the strength of information arguments. In the other side, the peripheral route may need less cognitive works, but focusing on the factors that may not be related to the information used by a consumer to access the information.

As mentioned earlier, there are two main dimensions of information credibility as proposed by Li and Suh (2015). The first one, medium credibility, refers to the degree of credibility who is perceived by information user towards a certain medium. And second, message credibility, refers to the credibility perception of the communicated message itself, such as information quality, accuracy, or currency. There are two research construct that were developed from these two dimensions. Firstly, the medium credibility which are affected by three factors: (1). Interactivity, the tendency to involve in an interaction, the perceive ease of interaction, and the degree of rapport that is activated; (2). Medium dependency, the feelings or perception of not having alternative other than specific media to get informed about reality; (3). Medium transparency, the individual willingness to share the information voluntarily and being frankly with others on a specific medium. Secondly, the message credibility which are affected by two factors: (1). Information quality, the matter of degree, ranging from the accurate and objective presentation to the currency of information; and (2). Argument strength, the extent to which a message receiver views that argument to be convincing or valid in supporting its position.

Based on this model as suggested by Li and Suh (2015) this research paper adopted two significant variables to examine the effect of credibility information in social media marketing being used to promote products and services offered by Indonesian SMEs for millennial-type consumers. Those two variables are medium credibility and message credibility. Further by adopting Nick Hajli's empirical study, this paper also want to examine whether the information credibility also contributes a significant impact towards the adoption of Social WOM, in the context of social media marketing for SMEs, while under different kind of country's socio-political condition compared to prior research. As reported by $\mathrm{PwC}$ research (Yusra, 2018), the raise of millennial consumers is the important key to market products and services by SMEs in the Southeast Asian countries or regions by 2020, whereby $57 \%$ of effective marketing promotion will be done through social media marketing, especially Facebook and Twitter. Further the viral marketing technique by using an effective visual technique is predicted to reach up to $44 \%$ through Instagram, Snapchat, Pinterest and YouTube. 
Figure 1. Research model

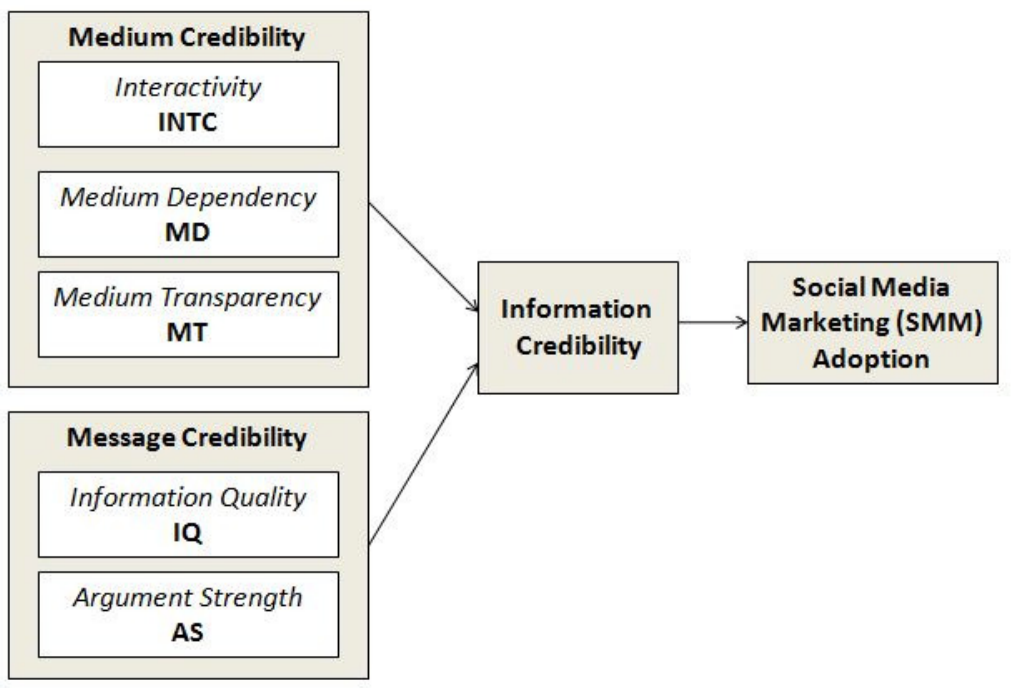

Since there was no further model developed based-on the adoption of social media marketing adoption or usage to market SME products and service, therefore the value of this paper lies in its contribution to propose a new research model that can be seen in the Figure 1. Prior studies from Hajli (2018) and Li and Suh (2015) were adopted in this study to develop the new model so as the researchers will able to understand how the information credibility may affect the adoption process of social media marketing strategy in the context of SME marketing strategy. This model has not been discussed before in the similar studies which tried to elaborate the credibility of social media networks for commercial purposes (Curtis, Edwards, Fraser, Gudelsky, Holmquist, Thornton, \& Sweetser, 2010; Johnson \& Kaye, 2004).

\section{Methodology}

This research used post-positivistic paradigm and quantitative research methodology approach which also been used by prior researches done by Li and Suh (2015), as well as Hajli (2018) to see if there is any different kind of effect compared to the new model as proposed in this research paper. To test the new model, authors adopt a survey method for data collection by applying the structural equation modeling (SEM) approach using the IBM SPSS Amos (analysis of moment structure) statistical software, to see the loading factors resulted in the computation. This SEM model has developed to examine the hypothesis development as follows: $\mathrm{H}_{1}$ : The medium credibility is positively related to Social WOM information credibility; $\mathrm{H}_{2}$ : The message credibility is positively related to Social WOM information credibility; $\mathrm{H}_{3}$ : The Social WOM information credibility is positively related to the Social WOM adoption. The unit analysis of this research is SMEs potential consumers who have typical millennial generational characteristics, in this case, those who are familiar with the usage of social media marketing and surf the Internet for more than three hours per day and categorized as "netizen" (MarkPlus, 2015).

To define the number of samples required by SEM model, this research refers to Hair, Black, Babin, Anderson, and Tatham (1970), which minimum required samples required is five times of total number of indicators. The data were collected via questionnaires distribution either through face-to-face or online survey by using purposive sampling technique. The authors used personal judgment on which samples that need to be taken, where the selection is based on typical respondent characteristics (Burns \& Bush, 2010). The questionnaires were structured by using multiple choice questions with 1-5 Likert scales to measure the respondents' answers, with additional open questions. The questionnaires were also available online by using Google Form survey tool. Reliability and validity tests were conducted for 31 respondents by using SPSS statistical software to check whether the questionnaires can be used as a reliable and valid tool to get the data. Since all of the computed value of Product Moment Pearson (r) was greater than r-table values, the questionnaires instrument was 
A study on information credibility in the social media marketing adoption: Evidence from Indonesia

considered as valid. Meanwhile the Cronbach Alpha values resulted in the computation were also greater and closer to .08, therefore the reliability of the questionnaires instrument was considered as good. This study was using purposive sampling technique as the authors used personal judgment sampling method based-on typical characteristics of respondents and easiness reasons (Burns \& Bush, 2010). Finally, there were around 400 questionnaires distributed manually or through online communities and after passing the sorting process, there were 234 respondents (38\% were males and $62 \%$ were females) who were considered to complete all of the questions properly. Most of them were using Instagram (50\%), Facebook (40\%), YouTube (7\%), and Twitter (3\%) users.

\section{Results and discussions}

The proposed research model is considered as recursive where all causal effects are uni-directional and disturbances are uncorrelated. The statistical parameters such as CMIN/DF, GFI, and RMR are used in this SEM analysis to decide whether the research model can be considered as good fit. Further based-on the computation output by using analysis tool of IBM SPSS Amos, it concluded that the goodness of fit of the proposed model is considered as acceptable since at least the three indexes calculated were at good fit or in acceptable criteria (see Table 1).

\section{Table 1}

Goodness of Fit Summary

\begin{tabular}{ccc}
\hline Measurement & Output & Goodness of Fit \\
\hline CMIN/DF & 3.024 & good fit \\
GFI & 0.939 & good fit \\
RMR & 0.020 & good fit \\
\hline Source: Author. & &
\end{tabular}

Based-on the research proposed model, the reports was generated by IBM SPSS Amos software computation (see Figure 2). As the results, the loading factor of the three indicators of Interactivity (INTC), Medium Dependency (MD), and Medium Transparency (MT) which measures the Medium Credibility, respectively are $.73 ; .62$; and .78. As for Message Credibility construct, this variable is measured respectively by Information Quality (.90) and Argument Strength (.81) indicators. According to Stevens (1992) the minimum loading factor value used to justify the strength or effectiveness of a variable to explain its latent variable is .4. The higher the value, the more important its role as a factor to affect another variable.

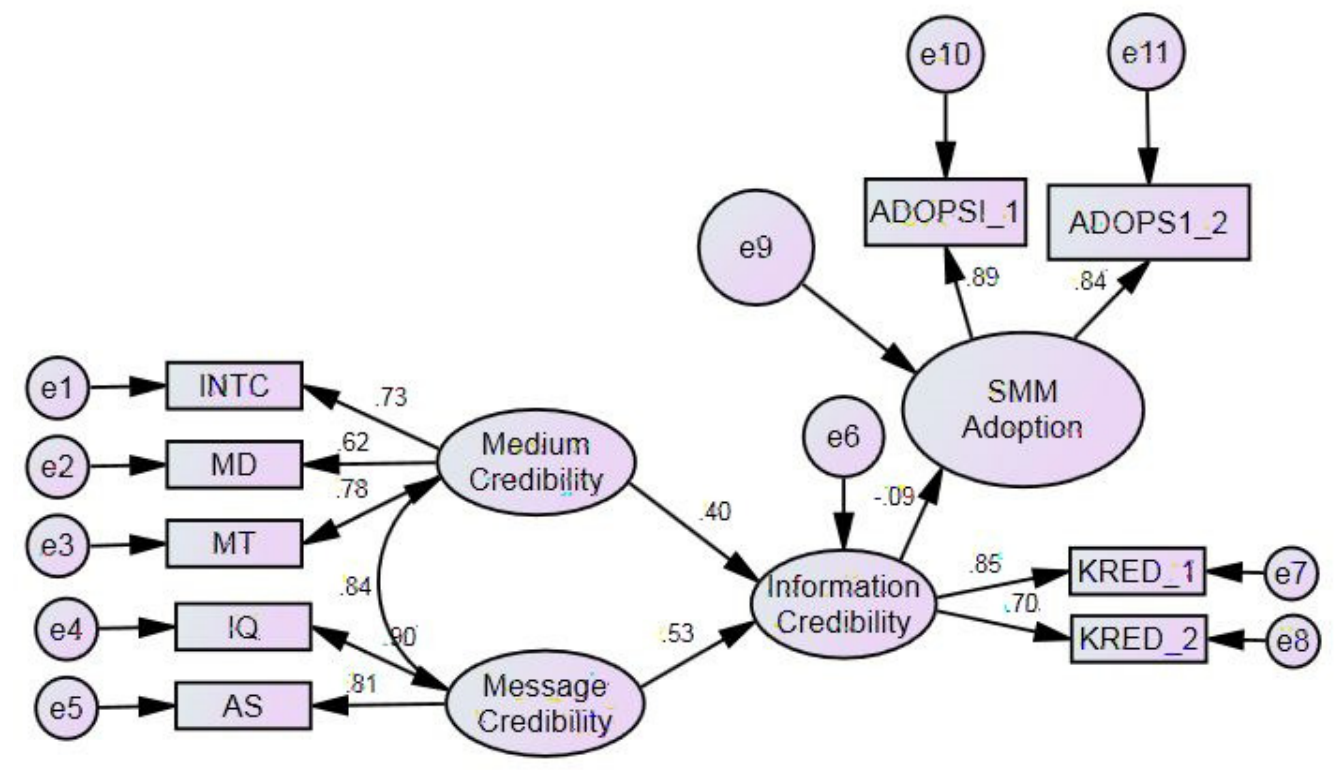

Figure 2. Research model analysis 
The Information Credibility latent variable is affected by two variables Medium Credibility and Message Credibility. How strong the two variables affect the Information Credibility is measured by two loading factor values of .40 (Medium Credibility) and .53 (Message Credibility). Meanwhile the Information Credibility was measured by two indicators which resulted in loading factor values of .85 and .70 respectively.

Based-on the above structural equation modelling computation, the study found that the Message Credibility was stronger compared to Medium Credibility in affecting the Information Credibility. Further, the Information Quality was stronger than Argument Strength. This finding implies that most of the respondents were perceived that to promote SMEs products and services by using social media marketing, firstly it shall give more accurate information, easy to be understood and fast, as reflected in a good information quality (IQ) indicator. Secondly, the consumer will also evaluate the argument strength (AS) which focus on its information validity and reasonable enough in their promotion messages. And the third is medium transparency (MT), whereby the consumer sees that a good social media marketing platform shall consider the information balance, non-bias and able to provide freedom to share the information. The interactivity factor (INTC) that facilitates suggestions, praise, recommendation, and many others. has more important role rather than the factor that encourages participation and provides information currency (MD).

Medium and Message Credibility variables were able to explain the Information Credibility variable as indicates in the correlation relationship between the latent variables which significantly affect each other (with loading factor of .84). Further, the Information Credibility first indicator (KRED_1) with loading factor of .85 was stronger than the second one (KRED_2) with loading factor of .70. It indicates that consumers perceive that it is important for them that social media marketing should provide credible information, rather than just understand that credibility is something important for them. However the relationship between Information Credibility and Social Media Marketing (SMM) Adoption variables did not show a positive relationship as indicated by -.09 loading factor, although both two indicators of adoption showed a strong loading factor.

Besides goodness of fit and loading factor indexes, the software also generated another statistical parameter that can be used to determine either the proposed hypothesis can be accepted or rejected. The results showed that the $p$-value resulted in the effect of Medium Credibility towards Information Credibility are .010. If the $p$-value is less than .05 , it means that the Medium Credibility is significantly influence the Information Credibility, thus the $\mathrm{H}_{1}$ hypothesis is accepted. Further, the P-value resulted in the effect computation of Message Credibility towards Information Credibility is shown as *** characters, and it means that the variable (Message Credibility) is very significantly affects the Information Credibility. It also means that the $\mathrm{H}_{2}$ hypothesis is accepted. Meanwhile, the $p$-value of .239 resulted in the computation indicated that the effect of Information Credibility towards the SMM Adoption was weak, because the $p$-value is more than $p$-value. In other words, the $\mathrm{H} 3$ hypothesis was rejected.

Based-on the test result, this research found that the latent variable of Medium Credibility was positively and significantly affecting the Information Credibility. It means that the information credibility in the social media marketing itself was affected by the features provided by the social media platform, in this case how good its interactivity, whether the platform help consumers to participate, understand and get the currency of information. One of the interesting features in the social media was designed to ease the communication beyond the time and distance constraints. As the recent global world is easily connected through the social media, therefore the social media network is one of interesting tools in-order the consumers keep in-touch with their peers and relatives or the communities that shared their common interests. Interactivity and currency were something that of important to the millennial nowadays, even it might reach up to the older generation category.

Starting as friendships platform, the social media network has been evolving its users since it's not only providing communication platform among the individuals. Nowadays corporations has also utilizing this platform in-order to improve its marketing communication performance, starting from the introduction of new products or brands, promoting, improve its sales performance and their customer loyalty (Solomon, 2010). 
A study on information credibility in the social media marketing adoption: Evidence from Indonesia

Based-on the finding of this study, the social media networks such as Instagram, Facebook, YouTube were the most popular medium used by most of the millennial respondents for information search other than search engines like Google, Yahoo! and Bing. Or in another words, it shows that the young consumers perceived that these social media platforms were credible or convenient enough to be used for commercial purpose.

The determinant factor of Medium Credibility, which is one of the dimensions of Information Credibility as suggested by Li and Suh (2015), indicated that the social media users perceive that the more popular social media used by their peers, relatives and communities, the more credible they are. This brought a similar effect to consumers who are looking for SME product information over the social media network. The millennials might just accept directly, select and consider carefully which social media that most popular among their peers, relatives and communities, and the message can be accepted directly through central route or take longer peripheral route as suggested by ELM theory. However the millennial-type consumers tend to accept directly rather take longer adoption.

Equipped with the advancement of security and privacy settings, the social media platforms have been improving their performance and images in the users' mind that might perceive more positively and finally improve its credibility as well. The users are given more freedom to control how they interact to their friends or communities over the social media. Psychologically the users might feel that the operation is 'in-control'. Other than security and privacy features, the social media platform also provides a user friendly interface that fits for all user categories. Instagram, for instance, is having the largest users in Indonesia, which is currently becoming the largest market in Asia with the number of subscribers reach up 45 millions (Adi \& Hidayat, 2017). This report was supported by the findings of the study which most of respondents perceive that Instagram is the most suitable social media marketing platform to promote SME products and services. The simplicity of its features make the Instagram is popular among the millennials. It mainly provide picture with short comments, so the marketer are able to post their products and get instant response or feedback from its audiences and their connections. This explains on how the medium credibility in social media marketing is significantly influencing its information credibility perceived by the consumers.

Not only Medium Credibility, the Message Credibility variable was also affecting significant positively in social media marketing of SME products and services. There are two indicators affecting the Message Credibility, they are: Information Quality and Argument Strength. The two indicators are having strong influence to shape the respondents' perception toward the Message Credibility as mentioned earlier. One of the advantages of social media marketing is on its capability to self-produce the content of message. It means that the discussions and comments about the offered products are generated by the users without direct involvement of marketers itself. Thus the solid social media platforms might enhance the self-creation or provide the enrichment or even weakening the information or promotional messages about the products. This feature is widely known as user-generated content (UGC) capability or sometimes in WOM social concept it is also called as consumer-generated content. The negative messages or contents might slower the persuasive communication process as suggested by ELM. In this context, the information process about the SME products and services may take longer route which is called as peripheral route.

The negative perception about any SME offered products or services is a challenging issue but also create advantages for social media marketers. In some occasions, the marketers might use it to acquire market response towards new offered products that requires faster cost-effective feedback required in a dynamic market competitions. Emotional engagement with customers is another driving factor led the marketers utilize more on social media marketing. The two indicators of information quality and argument strength might create the credibility of the message itself. It means that the more enhancement of the message on the quality and argument strength, the more likely it creates strong positive perception towards the social media credibility itself.

The test results found that Information Credibility variable was apparently less significant affected the Social Media Marketing (SMM) Adoption. It can be interpreted that the information credibility which was 
significantly affected by both medium and message credibility, was not necessarily showing a significant effect towards the adoption of social media marketing in the context of marketing promotion for SME products and services. Therefore the information credibility factor seen by respondents or consumers as something as if it was separated or very small significant affected the SMM adoption. Interestingly, this study shown that in the context of WOM social, the respondents or consumers might consider whether information is credible enough based-on the quality of interactive message communicated over the social media platforms. However in adopting the social media marketing, the consumers might not significantly consider the information credibility, so there might be another determinant factor such as effort expectancy that might contribute the significant effect towards the social media adoption (Venkantesh, Morris, Davis, \& Davis, 2003).

The finding of the study surprisingly found the insignificant effect between the information credibility and its social media marketing adoption, which was supported by another research conducted by Moran and Muzellec (2017). Based-on their study, they suggests that the use of online platform like eWOM and social media marketing might create a threat towards its information credibility itself. One of the major problems that increasingly developed currently is related to ethical issues which the consumers perceive that the marketing campaign over the Internet might be less sincere. In the perspective of ELM theory, this study found that persuasive communication processed through central and peripheral routes did not necessarily make the consumers automatically adopting the social media marketing as their channel to seek the product information. To explain this phenomenon in marketing context, before the consumers make decisions to use the social media marketing, they might consider another factors that might exist, such as: situational factors, usage context, how urgent the buying needs, moods, and purchase orientation as suggested by Solomon (2010). By using social media platform, consumers feel that they have available option and freedom to speak, make comments, recommendations, giving positive or negative reviews or feedbacks, so they feel they are able to control the information credibility itself.

\section{Recommendations, implications and limitations}

Based-on the discussion in the previous section, this study concludes that among the proposed three (3) hypotheses, there are two were accepted $\left(\mathrm{H}_{1}\right.$ and $\left.\mathrm{H}_{2}\right)$ and one $\left(\mathrm{H}_{3}\right)$ was rejected. The accepted hypotheses showed the strong significance of medium and message credibility factors that affect the information credibility in the context of social media marketing usage. The results support the former research model developed by $\mathrm{Li}$ and Suh (2015). Meanwhile, the information credibility itself did not show any significant effect towards the adoption of social media marketing as a marketing tool to promote SME products and services. Further research can be developed from the UTAUT theory is recommended to explain another socio-psychological factors such as system usefulness, ease of use, social influence and facilitating conditions that might contribute more significant influence towards the consumer behavioral aspect of social media marketing adoption.

Further this study found that the insignificant influence of information credibility towards the adoption of social media marketing might contribute a positive practical implication to the marketers. Although there have been many hoax information or messages spreads over the Internet nowadays, the SME social media marketing experts may be able to use this digital marketing strategy to reach more consumers with relatively lower promotional costs. At the other hand the wider consumers also may be able to get more choices to purchase alternative products they need both from global reputable brand producers as well as those of SME's. In the long run, besides for promotional purposes, the SME producers may be able to improve its quality and services from the feedbacks or comments generated by their consumers, so this social media marketing strategy may become one of their market research low-cost alternatives. Findings of this study also may suggest that marketing learners and teachers may consider important aspects that strongly influence the credibility of information through social media networks. They might learn and study further on how to be carefully select credible social media that provide transparent, interactive, updated, valid and qualified information, before sharing the marketing messages to the their peers and family members. 
A study on information credibility in the social media marketing adoption: Evidence from Indonesia

This research was also expected to enrich prior research on social media marketing communication by using quantitative analysis. As the disrupted digital innovation moves forward dynamically, the researchers in this area shall take attention especially in the design of questionnaire, because new technological terms may not be easily understood by all consumer segments. This study has the limitation of respondent in a broad segment category, therefore the authors may suggests the another researchers to pick more targeted consumer segment, in more categorized SME products and services. However hopefully the study may contribute a new perspective to understand deeper about the effect of information credibility in social media platform adoption in commercial or business context, which might be result differently from those that has been utilized to explain political research issues.

\section{References}

Adi, A., \& Hidayat, A. (2017, July 26). 45 Juta Pengguna Instagram, Indonesia Pasar Terbesar di Asia [45 Millions Subscribers of Instagram, Indonesia is the Largest Market in Asia]. Tempo.co. Retrieved from https://bisnis.tempo.co/read/894605/45-juta-pengguna-instagram-indonesia-pasar-terbesar-di-asia

Ali, H., \& Purwandi, L. (2016, February). The urban middle-class millennial Indonesia: Financial and online behavior. Jakarta: Alvara Research Center. Retrieved from https://alvara-strategic.com/wp-content/uploads/whitepaper/The-Urban-Middle-Class-Millenials.pdf

Badan Perencanaan Pembangunan Nasional, Badan Pusat Statistik, \& United Nations Population Fund. (2013). Proyeksi Penduduk Indonesia 2010 - 2035 [Indonesia population projection 2010 - 2035]. Retrieved from https://www.bps.go.id/publication/2013/10/07/053d25bed2e4d62aab3346ec/proyeksi-penduduk-indone sia-2010-2035.html

Belch, G. E., \& Belch, M. A. (2015). Advertising and promotion: An integrated marketing communications perspective (10 ${ }^{\text {th }}$ ed.). Singapore: McGraw Hill Education.

Burns, A. C., \& Bush, R. F. (2010). Marketing research. Global edition (6 ${ }^{\text {th }}$ ed.). New Jersey: Pearson Education, Inc.

Campbell, C., Pitt, L. F., Parent, M., \& Berthon, P. R. (2011). Understanding consumer conversations around ads in a web 2.0 world. Journal of Advertising, 40, 87-102. https://doi.org/10.2753/JOA0091-3367400106

Charlesworth, A. (2015). An introduction to social media marketing. London \& New York: Routledge Taylor \& Francis Group. https://doi.org/10.4324/9780203727836

Cort, A. (2014, April 2). SMEs are frustrated with their websites. Browsermedia.agency. Retrieved from https://browsermedia.agency/blog/smes-frustrated-websites/

Curtis, L., Edwards, C., Fraser, K. L., Gudelsky, S., Holmquist, J., Thornton, K., \& Sweetser, K. D. (2010). Adoption of social media for public relations y nonprofit organizations. Public Relations Review, 36(1), 90-92. https://doi.org/10.1016/j.pubrev.2009.10.003

Hair, J. F., Black, B., Babin, B., Anderson, R. E., \& Tatham R. L. (2006). Multivariate data analysis (6 ${ }^{\text {th }}$ ed.). New Jersey: Prentice Hall International, Inc.

Hajli, N. (2018). Ethical environment in the online communities by information credibility: A social media perspective. Journal of Business Ethics, 149(4), 799-810. https://doi.org/10.1007/s10551-016-3036-7

Hillery, G. A. (1955). Definitions of community: Areas of agreement. Rural Sociology 20(2), 111-123.

International Finance Corporation (IFC) Worldbank Group, \& United States Agency for International Development (USAID). (2016). Women-owned SMEs in Indonesia: A golden opportunity for local financial institution. Retrieved from https://www.ifc.org/wps/wcm/connect/677906e9-398d-45c1-8f87-84e503292f50/SME+Indonesia+Fina 1_Eng.pdf?MOD=AJPERES

Johnson, T. J., \& Kaye, B. K. (2004). Wag the blog: How reliance on traditional media and the Internet influence credibility perceptions of weblogs among blog users. Journalism \& Mass Communication Quarterly, 81, 622-642. https://doi.org/10.1177/107769900408100310

Li, R., \& Suh, A. (2015). Factors influencing information credibility on social media platforms: Evidence from 
Winarko, H. B., Sihabudin, A., \& Dua, M.

Facebook pages. Procedia Computer Science, 72, 314-328. https://doi.org/10.1016/j.procs.2015.12.146

MarkPlus, Inc. (2015, September). Youth, women, netizen (YWN)'s social media habit survey. Marketeers Magazine.

Miller, K. (2005). Communication theories: Perspectives, processes and context ( $2^{\text {nd }}$ ed.). Singapore: McGraw Hill.

Morran, G., \& Muzellec, M. (2017). eWOM credibility on social networking sites: A framework. Journal of Marketing Communications, 23(2), 149-161. https://doi.org/10.1080/13527266.2014.969756

Parsons, E., \& Maclaran, P. (2009). Contemporary issues in marketing and consumer behavior. New York: Routledge. https://doi.org/10.4324/9780080943169

Petty, R. E., \& Cacioppo, J. T. (1986). The elaboration likelihood model of persuasion. Advances in Experimental Social Psychology, 1, 123-205. https://doi.org/10.1016/S0065-2601(08)60214-2

Priambodo, B. (2016, December 14). Hasil Survei Kepercayaan terhadap Berita Online [Trust survey report towards online news]. Medium.com. Retrieved from https://medium.com/@bobbypriambodo/hasil-survei-kepercayaan-terhadap-berita-online-d09afb702219

Solomon, M. R. (2010). Consumer Behavior: Buying, Having and Being, Global Edition, (9 ${ }^{\text {th }}$ ed.). Pearson.

Straubhaar, J., LaRose, R., \& Davenport, L. (2012). Media now: Understanding media, culture and technology. Boston, MA: Wadsworth Cengage Learning.

Stevens, J. P. (1992). Applied multivariate statistics for the social sciences ( $2^{\text {nd }}$ ed). Hillsdale, NJ: Lawrence Erlbaum Associates, Inc.

Tambunan, T. T. H. (2008). Development of SMEs in ASEAN. New Delhi: Readworthy Publications, Ltd.

Tambunan, T. T. H. (2009). SMEs in Asian developing countries. UK: Palgrave Macmillan. https://doi.org/10.1057/9780230250949

Tuckwell, K. J. (2008). Integrated marketing communications: Strategic planning perspectives ( $2^{\text {nd }}$ ed.). Toronto: Pearson-Prentice Hall.

Tuten, T. L., \& Solomon, M. R. (2018). Social media marketing ( $3^{\text {rd }}$ ed.). Thousand Oaks, CA: Sage Publications Ltd.

Venkatesh, V., Morris, V., Davis, G., \& Davis, F. (2003). User acceptance of information technology: Toward a unified view. MIS Quarterly, 27(3), 25-78. https://doi.org/10.2307/30036540

Yusra, Y. (2018, July 6). Tren dan Lanskap Pemasaran Digital di Indonesia [The trend and landscape of digital marketing in indonesia]. dailysocial.id. Retrieved from https://dailysocial.id/post/tren-dan-lanskap-pemasaran-digital-di-indonesia 